\title{
HTML5 IN EDUCATION AT THE DEPARTMENT OF COMPUTER SCIENCE OF THE FACULTY OF EDUCATION AT THE UNIVERSITY OF SOUTH BOHEMIA, ČESKÉ BUDĚJOVICE, CZ
}

\begin{abstract}
Petr PEXA
Abstract: The article informs about innovation of subjects Administration and Design of Education Website I and II that are being lectured at the Department of Computer Science of the Faculty of Education at the University of South Bohemia. The innovation itself relates especially to individual functions, components and tools of the new HTML5 technology. Nearly every new version of web browsers includes better support of new languages and technologies dedicated to building websites. This ensures that many effects which were previously impossible to use in browsers due to their different support are gradually becoming meaningful. HTML5 brings many new features and enhancements that enable us to create more modern and overall more interesting websites than ever before and that are supported in current versions of web browsers including Internet Explorer 10 from 2012.
\end{abstract}

Key words: Information and communication technology, teaching computer science, website creation, administration and designing educational website, HTML5, CSS3, web forms, Drag and Drop, geolocation, HTML5 audio and video, animations, web browsers, Internet Explorer, Google Chrome, Mozilla Firefox, Opera, Safari, mobile web browsers.

\section{TECHNOLOGIE HTML5 VE VÝUCE NA KATEDŘE INFORMATIKY PEDAGOGICKÉ FAKULTY JIHOČESKÉ UNIVERZITY V ČESKÝCH BUDĚJOVICÍCH}

Resumé: Článek seznamuje s inovací předmětů Správa a navrhování edukačního webu I a II, vyučovaných na katedře informatiky Pedagogické fakulty Jihočeské univerzity v Českých Budějovicích, která se týká především jednotlivých funkcí, prvků a nástrojů nové technologie HTML5. Téměř každá nová verze webových prohlížečủ má implementovánu lepší podporu nových jazyků či technologií určených pro tvorbu webových stránek. Tím je zajištěno, že mnohé efekty, které dřive nebylo možné vzhledem $\mathrm{k}$ jejich rozdílné podpoře $\mathrm{v}$ prohlížečích použít, se stávají postupně smysluplnými. HTML5 přichází s mnoha novinkami a vylepšeními, které nám dovolují vytvářet modernější a celkově zajímavější webové stránky než tomu bylo doposud a v aktuálních verzích webových prohlížečů včetně Internet Exploreru 10 z r. 2012 jsou již podporovány.

Klíčová slova: Informační a komunikační technologie, výuka informatiky, tvorba www stránek, správa a navrhování edukačního webu, HTML5, CSS3, webové formuláře, Drag and Drop, geolokace, HTML5 audio, a video, animace, webové prohlížeče, Internet Explorer, Google Chrome, Mozilla Firefox, Opera, Safari, mobilní prohlížeče.

\section{1 Úvod}

V roce 2012 byly vývojáři nejpouživanějších webových prohlížečů zveřejněny verze podporující již většinu postupů a technik, které nabízí nová technologie pro tvorbu webových stránek s názvem HTML5.

U prohlížečů Google Chrome, Mozilla Firefox, Opera a Safari se o pŕiliš velké překvapení nejedná, ale revolučních změn v kvalitě doznal především Internet Explorer 10, jehož předchozí verze často nesplňovaly kritéria a standardy moderních webových prohlížečů. Jelikož je ovšem Explorer v součtu všech existujících verzí dle dostupných statistik stále nejpoužívanějším prohlížečem a jeho starší verze (především Explorer 8 pod operačním systémem Windows XP) technologii HTML5 téměř vůbec nepodporovaly, nebylo možné na webových stránkách mnohé nové techniky používat.

Tato situace se tedy změnila v r. 2012 a mnohé efekty, které dř́ve nebylo možné vzhledem $\mathrm{k}$ jejich rozdílné podpoře v prohlížečích uplatnit, se stávají postupně smysluplnými jak pro webové designéry, tak pro vyučují informačních a komunikačních technologií na středních, vyšších odborných a vysokých školách, které se zabývají přípravou odborníků v oblasti webového designu. $\mathrm{Na}$ 
katedře informatiky Pedagogické fakulty Jihočeské univerzity $\mathrm{v}$ Českých Budějovicích jsou již dlouhá léta vyučovány předměty Tvorba www stránek a Správa a navrhování edukačního webu I a II, do jejichž programu byly aktuálně v uplynulých dvou semestrech funkční HTML5 techniky zařazeny.

\section{Co je HTML5?}

Hlavní technikou pro tvorbu základního datového kódu webu je stále klasický jazyk HTML, ale ve své nové verzi s označením HTML5 se zcela změnil obsah tohoto pojmu. I nadále zahrnuje sestavu původních a mnoha nových elementů a atributů pro popis struktury obsahu webové stránky, ale současně byly pod tento termín zahrnuty i další, původně samostatné webové technologie.

Mezi nejzajímavější patř́ jazyk kaskádových stylů pro pokročilé formátování webu (aktuálně ve verzi CSS3), technologie mikroformátů (HTML5 Microdata), jazyk SVG pro tvorbu vektorové webové grafiky či jazyk SMIL pro tvorbu multimediálních prezentací. Dále také několik nových API (Application Programming Interface), jako např. Geolocation API pro využívání geografické polohy na webu, Drag and Drop API (technika pro interaktivní přesuny objektů v rámci webu) a technologie pro tvorbu nových webových formulářu (HTML5 Forms), webových animací, zvuků a videí (HTML5 audio a video) a vkládání dynamických grafických objektů (HTML5 Canvas).

Je ale třeba zdůraznit, že specifikace HTML5 není ještě zcela dokončena a standardizována organizací W3C (World Wide Web Consortium), její použití bylo tedy donedávna považováno spíše za experimentální. Ovšem vzhledem $\mathrm{k}$ výrazné podpoře $\mathrm{v}$ aktuálních verzích prohlížečů je již nasazení této technologie na webové stránky v současné době možné, o čemž svědčí zdrojové kódy Googlu, Facebooku, Youtube, českého Seznamu a dalších známých webových projektů.

\section{Výhody a nevýhody HTML5}

Uved'me nejprve jedinou nevýhodu, která s využitím technologie HTML5 souvisí a to již zmíněnou nepodporu ve verzi Internet Explorer 8, kterou lze jako jedinou nainstalovat pod Windows XP (Explorer 9 resp. 10, které s HTML5 již problém nemají, jsou funkční pouze ve Windows 7 resp. Windows 8).

Existují nějaká řešení tohoto problému? Nabízejí se dvě - standardní variantou je vytvoření alternativní verze webu bez HTML5 prvků s využitím JavaScriptových objektů navigator a location pro automatické přsměrování na webovou stránku pro dnes již zastaralý prohlížeč Explorer 8 (více napřr. v úvodu zdrojového kódu titulní stránky webu na www.petrpexa.cz).

Druhou (a mnohem jednodušší variantou) je použití JavaScriptové knihovny HTML5shiv (ke stažení na https://github.com/aFarkas/html5shiv), jejíž instalace je velice jednoduchá - stáhneme tuto knihovnu, uložíme jí do složky, kde máme vytvořenou HTML5 webovou stránku nebo aplikaci a pak se pouze $\mathrm{v}$ hlavičce webové stránky na tuto knihovnu odkážeme. Pak můžeme vytvářet HTML5 stránky nebo aplikace, které budou fungovat i ve všech starších prohlížečích.

Jednoznačně ovšem převažují výhody této nové technologie pro tvorbu moderních webů. HTML5 především zavádí celou sadu nových elementů, které významně usnadňují strukturování stránek a pomohou nám v praxi plnit teorii tzv. sémantického webu. V něm mají informace přidělen jasně definovaný význam lépe umožňující počítačům a lidem vzájemně spolupracovat. Jinak řečeno - data prezentovaná na internetu by měla mít přesně definovaný význam a dovolovat do značné míry automatizované (strojové) zpracování.

Díky aktuální verzi jazyka CSS3 jsou dále $\mathrm{k}$ dispozici nové možnosti $\mathrm{v}$ navrhování designu webu - aplikování stínu textu i objektů, zaoblených rohů jednotlivých obsahových boxů, gradientů (přechodových výplní), pokročilá práce s průhledností, využití mnoha druhů transformací a animací webových prvků (podrobnosti $\mathrm{v}$ dalších kapitolách článku). Tyto efekty bylo možné do jisté míry používat i dř́ve, ale pouze s pomocí mnohem složitějších programových sekvencí $v$ jazyce JavaScript nebo časově náročnou tvorbou grafických prvků ve specializovaném grafickém software (Adobe Photoshop apod.), které ale významně zvyšovaly datovou velikost webové stránky a tím způsobovaly její pomalejší načítání.

\section{Základní datový kód webu v HTML5}

Významné změny se objevily hned v základní kostře webové stránky - odpadá XML deklarace v úvodu kódu, komplikovaná deklarace typu dokumentu (tzv. DTD - Document Type Definition) a zjednodušeně je definována použitá znaková sada (UTF-8, Unicode Transformation Format, způsob kódování řetězců znaků). 


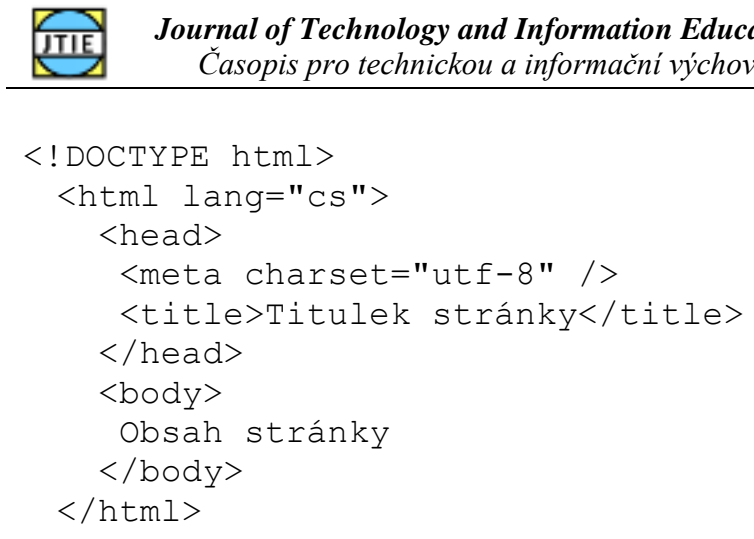

Konkrétní obsah stránky je dnes většinou tvořen klasickou skupinou obvyklých částí, jako je hlavička, patička, sloupce a dílčí sekce, přičemž se tyto části běžně vyznačují pomocí mnoha tradičních elementů 〈div> odlišených prostřednictvím popisných atributů id a class. Užití elementu <div> je dáno především tím, že starší verze jazyka HTML resp. XHTML postrádaly nezbytné sémantické prvky pro přesnější vyznačení specifických částí webu. HTML5 proto řeší tento problém zavedením nových elementů reprezentujících tyto jednotlivé části webové stránky - jedná se o značky

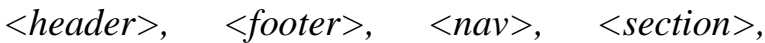
$\langle$ article $\rangle,\langle$ aside $\rangle$, jejichž význam dobře vidíme na obr. 1 a obr. 2.

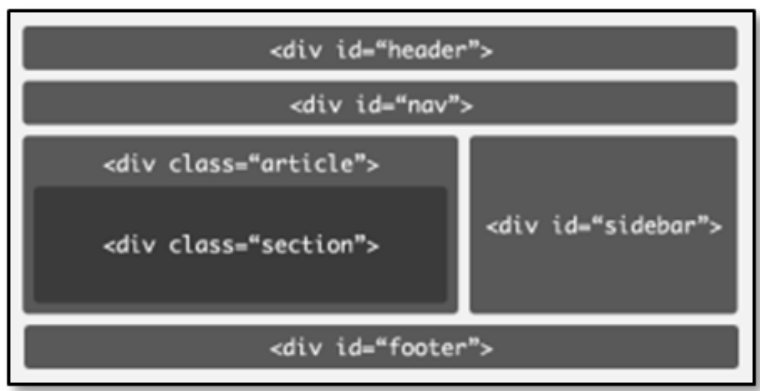

Obr. 1: Klasická struktura webu

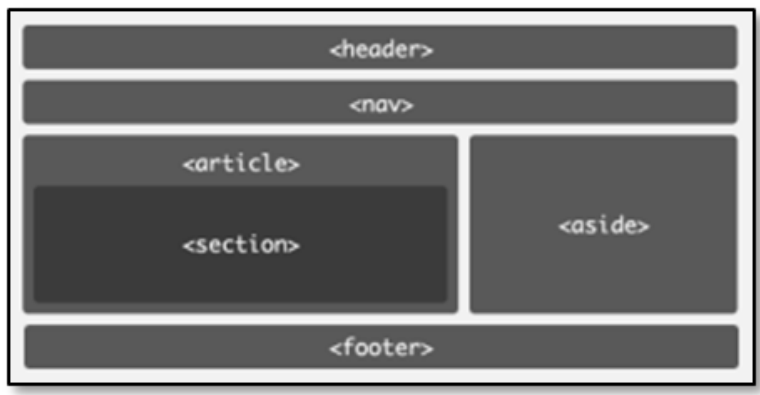

Obr. 2: Struktura webu v HTML5

První schéma ukazuje typický dvousloupcový layout vyznačený elementy 〈div> s atributy id a class. Obsahuje hlavičku, patičku a navigační lištu těsně pod hlavičkou. Hlavní obsah je tvořen článkem a vedlejším sloupcem umístěným vpravo. Element 〈div> je v HTML5 variantě nahrazen novými elementy $\langle$ header $\rangle$, 〈footer $\rangle$, $\langle$ nav $\rangle,\langle$ section $\rangle,\langle$ article $\rangle$ a 〈aside $\rangle$, odpadá tak nutnost přiřazení tříd či identifikátorů, celý kód je mnohem přehlednejš̌í a respektuje pravidla pro kódování dat sémantického webu. Pro formátování těchto nových elementů pak použijeme klasické CSS včetně zmíněných nových efektů verze CSS3.

\section{Webové formuláře v HTML5}

HTML5 prrináší mnoho změn i $v$ oblasti tvorby webových formulárùn. Jedná se zejména o rozšíření atributů pro element <input />, které výrazně ulehčují práci $\mathrm{s}$ některými druhy dat. Programátoři tak opět nemusejí tvořit složité skripty na kontrolu správnosti vkládaných dat, uživatelé pak využijí vyššího komfortu při jejich zadávání. Jako typický př́klad uved'me např. atributy number a date, které povolí zadání pouze čísla a konkrétního data, ve druhém případě i pomocí uživatelsky komfortního grafického rozhraní (obr. 3).

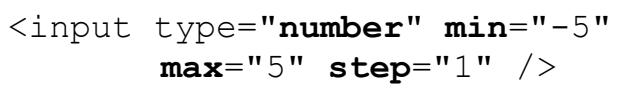

\begin{tabular}{l}
\begin{tabular}{|ccccccc|}
\hline dd. rm. rrrr & $\vdots \mathbf{v}$ \\
\hline po & út & st & čt & pá & so & ne \\
\hline 25 & 26 & 27 & 28 & 29 & 30 & 31 \\
1 & 2 & 3 & 4 & 5 & 6 & 7 \\
8 & 9 & 10 & 11 & 12 & 13 & 14 \\
15 & 16 & 17 & 18 & 19 & 20 & 21 \\
22 & 23 & 24 & 25 & 26 & 27 & 28 \\
29 & 30 & 1 & 2 & 3 & 4 & 5 \\
\hline Dnes & & & & & \\
\hline
\end{tabular} \\
\hline
\end{tabular}

Obr. 3: Vstupní pole pro zadání data

<input type="date" />

U vstupních formulářových polí je možné také zobrazit předdefinovaný řetězec (obr. 4) či kontrolovat, zda je pole před odesláním dat vyplněno (obr. 5) opět bez nutnosti současného použití JavaScriptu.

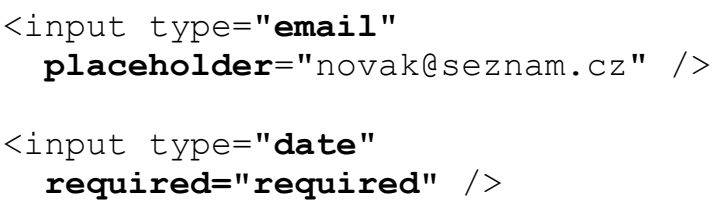


hovak@seznam.cz

Obr. 4: Předvyplněný retězec v poli

\section{dd. rm. rrrr $\div \mathbf{v}$ \\ Vyplňte prosím toto pole.}

\section{Obr. 5: Kontrola vyplnění pole}

Novinkou je také prvek pro výběr barvy, posuvník pro ovládání hlasitosti a možnost využití jednoduchého našeptavače tak, jak ho známe z vyhledávacího pole Googlu či Seznamu. Novinek je nejen v této oblasti tolik, že by určitě pouhé ukázky formou obrázků nesplnily účel tohoto článku, praktické př́klady na většinu nových HTML5 efektů lze proto nalézt na testovací stránce http://www.petrpexa.cz/html5/.

\section{HTML5 audio a video}

Problematika přehrávání multimediálního obsahu je jednou z nejstarších navrhovaných HTML5 technologií. Hlavní myšlenkou je zavedení tzv. nativní podpory, tedy možnosti přehrávání zvuku a videa bez nutnosti instalace externích přehrávačů či plug-inů (doplňků) do webového prohlížeče. Jedná se tak o náhradu napřr. přehrávače FlashPlayer, který nemá podporu v operačním systému iOS firmy Apple.

Jak již ale bylo uvedeno výše, celá technologie HTML5 je stále ve vývoji (k definitivnímu schválení má dojít v r. 2015, dle některých zdrojů až v r. 2022), a tak nebylo zatím stanoveno, v jakém standardizovaném formátu (resp. kodeku) musí být zvuk či video uloženy.

U zvuku se jedná především o komerční MP3 (který zatím podporují Google Chrome, Safari a Explorer) a open-source OGG (podpora ve Firefoxu a Opeře). Všechny tradiční prohlížeče kromě Exploreru také dokonce podporují nekomprimovaný formát WAV.

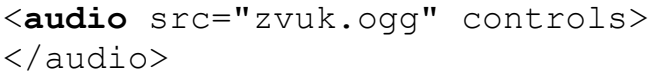

Pro videozáznamy přicházejí v úvahu opensource kodek OGG/Theora (zatím nativní podpora v prohlížečích Google Chrome, Opera a Firefox), komerční kodek MP4/H.264 (podpora v Google Chrome, Explorer a Safari), největší šance jsou v současné době přikládány novému open-source kodeku VP8/WEBM, který má (zatím s určitými úpravami) podporu ve všech pěti nejrozšířenějších prohližečích.

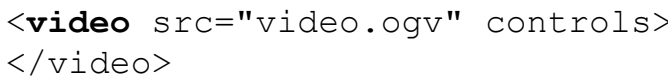

Populární videoportál Youtube zprovoznil podporu přehrávání HTML5 videa experimentálně od počátku r. 2010, ale pouze s komerčním kodekem MP4/H.264. Google poté začal propagovat volný kodek VP8/WEBM, jehož podpora je již na Youtube také.

Přestože je tedy element 〈video〉 určitě budoucností webových multimédií, panuje zatím mezi zainteresovanými webovými firmami jakási "technologická schizofrenie" a tak zatím nezbývá než vkládat na web video ve více formátech a nadále spoléhat i na tradiční Flash.

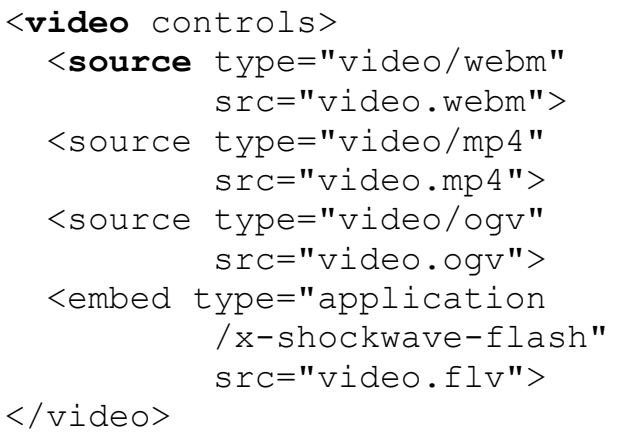

\section{CSS3}

Cílem každého tvůrce stránek je mít svi̊j web nejen obsahově zajímavý, často navštěvovaný, SEO (Search Engine Optimization) technikami optimalizovaný pro vyhledávací služby a syntakticky validní. Značnou roli zejména u stránek s komerčním a edukačním obsahem tvoří také intuitivnost, uživatelsky přívětivé ovládání s př́ístupností pro handicapované (tzv. Blind Friendly Web) a především jeho graficky zajímavý, netradiční a přitažlivý design. Tuto poslední vlastnost moderních webových stránek nám pomůže splnit jazyk kaskádových stylů ve verzi CSS3 jako jedna z hlavních součástí technologie HTML5.

Výše již byly některé nové vlastnosti představeny, uved'me tedy př́slušné ukázky zdrojových kódů a výsledné grafické zobrazení. Zájemce může opět navštívit praktické př́klady na http://www.petrpexa.cz/html5.

Není již potřeba kreslit ve Photoshopu ozdobné nápisy se stínem, protože kromě technologie tzv. dynamických fontů (viz dále) lze velmi snadno použít CSS efekt stínu (obr. 6). 
hl\#stin \{ text-shadow: 3px 3px 3px gray; \}

\section{Tématický plán předmětu KIN/WWW1A}

\section{Obr. 6: Stín textu}

Obdobnou techniku lze použít také u libovolného jiného objektu na webu (tabulky, obrázku, ohraničeného článku apod., obr. 7).

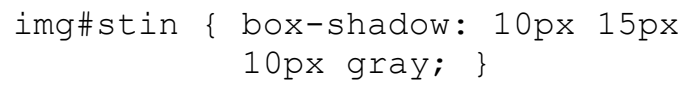

Efekt stínu kolem libovolného boxu (CSS3 vlastnost box-shadow). Efekt stínu kolem libovolného boxu (CSS3 vlastnost

box-shadow). Efekt stínu kolem libovolného boxu (CSS3 vlastnost box-shadow).....

Efekt stínu kolem libovolného boxu (CSS3 vlastnost box-shadow). Efekt stínu kolem libovolného boxu (CSS3 vlastnost

box-shadow). Efekt stínu kolem libovolného boxu (CSS3 vlastnost box-shadow).....

Obr. 7: Stín a zaoblené rohy objektu

Velmi populárním efektem jsou zaoblené rohy u původně hranatých objektů (obr. 7b) a libovolná úroveň průhlednosti (obr. 8).

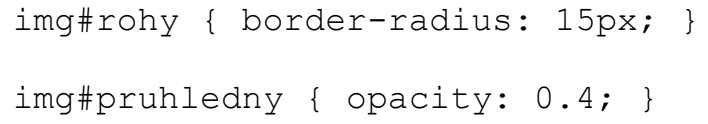

Mezi nejnovější grafické efekty v souvislosti

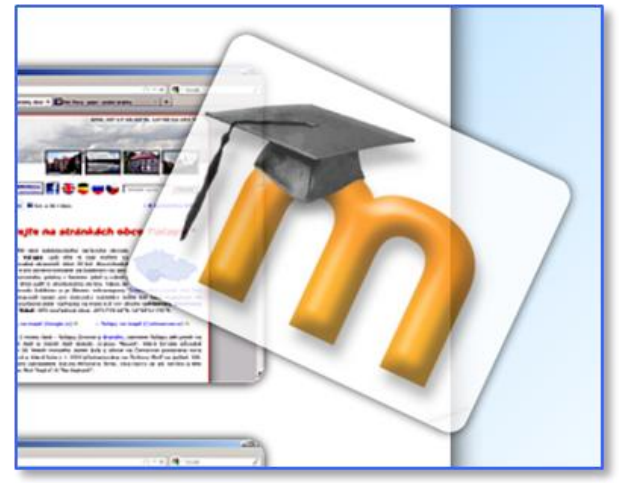

Obr. 8: Prühlednost a rotace objektu

s podporou $\mathrm{v}$ prohlížečích patří možnost přechodové výplně (tzv. gradientu) v lineární i radiální variantě (obr. 9) a otočení objektu o libovolný úhel (obr. 8).

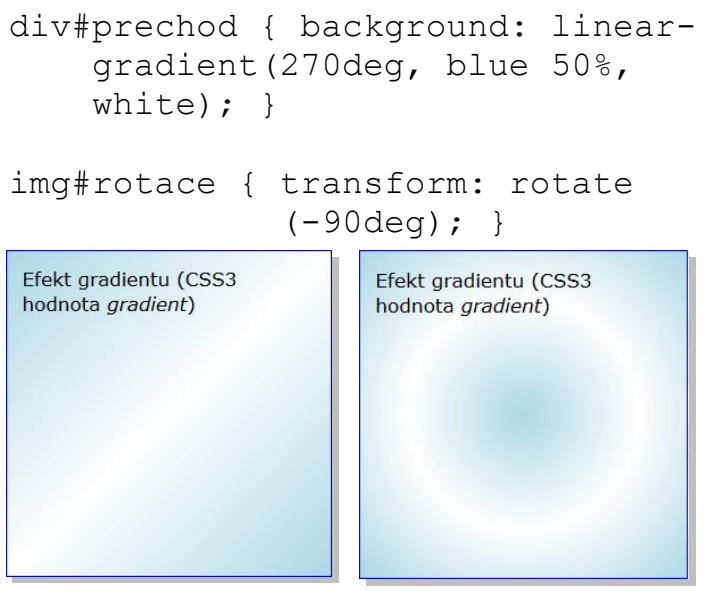

Obr. 9: Efekt lineárního a radiálního gradientu

Nejen působivé grafické efekty nám jazyk CSS3 pomůže vytvářet, ale umožní nám na webové stránce použít i libovolné písmo, které na počítači návštěvníka webu není nainstalováno. Zvolený font se umístí na server, následující deklarací je stažen ze serveru spolu se stránkou a na ní se text formátovaný tímto fontem zobrazí.

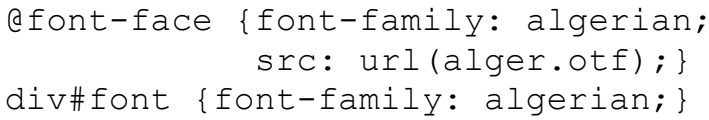

Závěrem této kapitoly přibližme ještě zřejmě největší novinku, která s CSS3 souvisí, a to jsou dynamické interaktivní animace. Pouhým najetím myší na libovolný objekt můžeme zajistit jeho plynulé otočení, změnu barvy, plynulé prolnutí s jiným objektem či dokonce přesun objektu z původního místa na jiné ve spolupráci s jQuery knihovnou (Drag and Drop API).

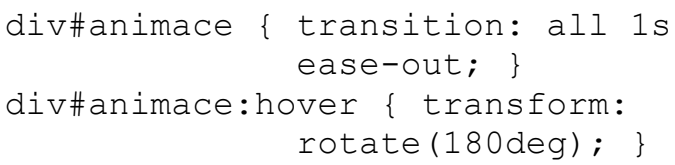

\section{Závěr}

Existuje ještě mnoho dalších HTML5 technik, které již byly zmíněny v úvodní kapitole (Geolocation API, Canvas, HTM5 Microformats, SVG, SMIL, Off-line Applications), jejichž detailní popis by vydal na několik dalších samostatných článků.

Zájemce tedy opět může využít webovou stránku http://www.petrpexa.cz/html5/, kde lze další informace nalézt ve formě ukázkových př́kladů včetně použitých zdrojových kódů. Tyto př́klady jednoznačně ukazují perspektivu této 
technologie, která nabízí na jedné straně jednodušší a rychlejší tvorbu webu, na druhé straně umožňuje navrhnout a především konečně realizovat jeho profesionální design s moderním (i dotykovým) ovládáním. Testy autora článku totiž potvrdily nejen podporu v nových desktopových webových prohlížečích, ale také v nativních prohlížečích „chytrých“ mobilních zařízení soperačními systémy Android, WindowsPhone, iOS (iPhone/iPad) a BlackBerry.

Tvorba webových stránek je dnes na různé odborné úrovni vyučována nejen na informatických katedrách mnohých vysokých škol, specializovaných vyšších odborných či středních odborných školách, ale poměrně často jako volitelný předmět i v závěrečných ročnících ve všeobecně vzdělávacích středoškolských institucích. Na rozdíl od výuky klasického strukturovaného programování má ovšem tato problematika $u$ většiny studentů mnohem výraznější oblibu, protože nevyžaduje př́liš hluboké odborné znalosti a schopnosti (ve srovnání např. s výukou programování v jazycích Java či $\mathrm{C} / \mathrm{C}++/ \mathrm{C} \#$ ) a student velmi brzy vidí poměrně kvalitní výsledky své práce. K tomuto stavu jistě může významně přispět i nová technologie HTML5.

\section{Literatura}

[1] GOLDSTEIN, A., LAZARIS, L., WEYL, E. HTML5 a CSS3 pro webové designéry. Brno:
Zoner Press, 2011. 286 s. ISBN 978-80-7413166-0.

[2] HAWRYLUK, Z. HTML5 \& CSS3 Support: Web forms 2.0. In: HTML5 \& CSS3 Support [online]. 2013 [cit. 2013-07-12]. Dostupné z: http://fmbip.com/litmus/.

[3] HOLDENER, A. HTML5 Geolocation. Sebastopol, CA: O'Reilly, 2011. ISBN 14-4930472-9.

[4] LUBBERS, P., ALBERS, B., SALIM, F. HTML5 - programujeme moderni webové aplikace. Brno: Computer Press, 2011. 304 s. ISBN 978-80-251-3539-6.

[5] PFEIFFER, S. HTML5 audio a video. Brno: Zoner Press, 2011. 350 s. ISBN 978-80-7413147-9.

[6] PILGRIM, M. HTML5: up and running. Sebastopol, CA: O'Reilly, 2010. ISBN 05-9680602-7.

[7] W3Schools: HTML5 [online]. 2013 [cit. 201307-13]. Dostupné z:

http://www.w3schools.com/html/html5_intro.asp

PaedDr. Petr Pexa, Ph.D.

Katedra informatiky

Pedagogická fakulta JU

Jeronýmova 10

371 15, České Budějovice, ČR

Tel: +420603327 457

E-mail: pexa@pf.jcu.cz

Www pracoviště: http://wvc.pf.jcu.cz/ki 